\title{
Physiological responses of plants to in vivo XRF radiation damage: insights from elemental, histochemical, anatomical and ultrastructural analyses
}

\author{
Gabriel S. Montanha ${ }^{1, \dagger}$, João P. R. Marques ${ }^{2, \dagger}$, Eduardo S. Rodrigues ${ }^{1}$, Michael W. M. Jones ${ }^{3}$ and Hudson W. \\ P. de Carvalho ${ }^{1, *}$
}

\begin{abstract}
${ }^{I}$ Centre for Nuclear Energy in Agriculture, Laboratory of Nuclear Instrumentation, University of São Paulo, Brazil ${ }^{2}$ Department of Basic Sciences, Faculty of Animal Science and Food Engineering, University of São Paulo, Brazil ${ }^{3}$ Central Analytical Research Facility, Institute for Future Environments, Queensland University of Technology, Australia
\end{abstract}

\author{
${ }^{\dagger}$ These authors contributed equally to this work \\ *For correspondence: hudson@cena.usp.br
}

\begin{abstract}
X-ray fluorescence spectroscopy (XRF) is a powerful technique for the in vivo assessment of plant tissues. However, the potential X-ray exposure damages might affect the structure and elemental composition of living plant tissues leading to artefacts on the recorded data. Herein, we exposed soybean (Glycine max (L.) Merrill) leaves to several X-ray doses through a polychromatic benchtop microprobe X-ray fluorescence spectrometer, modulating the photon flux by adjusting either the beam size, focus, or exposure time. The structure and physiological responses of the irradiated plant tissues were investigated through light and transmission electron microscopy (TEM). Histochemical tests were also conducted. Depending on the dose, the X-ray exposure induced decreased $\mathrm{K}$ and X-ray scattering intensities, and increased $\mathrm{Ca}$, P, and Mn signals on soybean leaves. Anatomical analysis indicated necrosis of the epidermal and mesophyll cells on the irradiated spots, where TEM images revealed the collapse of cytoplasm and cell-wall breaking. Furthermore, the histochemical analysis detected the production of reactive oxygen species, as well as inhibition of chlorophyll autofluorescence in these areas. Under certain X-ray exposure conditions, e.g., high photon flux and exposure time, XRF measurements may affect the soybean leaves structures and ultrastructure, elemental composition, cellular ultrastructure, and induce programmed cell death. These results shed light on the characterization of the radiation damage, and thus, help to assess the X-ray radiation limits and strategies for in vivo for XRF analysis.
\end{abstract}

Key Words: Soybean (Glycine max), X-ray fluorescence microscopy, radiation damage, plant anatomy

\section{INTRODUCTION}

Understanding plant functioning is crucial for increasing their efficiency in providing food, fibre, energy, and raw materials for the industry, as well as fostering environment preservation. In this scenario, X-ray fluorescence spectroscopy (XRF) has been widely employed to explore the elemental composition and spatial distribution in a myriad of botanical materials (van der Ent et al. 2018; Gomes et al. 2019; Montanha et al. 2020a; Lau et al. 2020; Romeu et al. 2021; Macedo et al. 2021). New generations of XRF instrumentation, i.e., faster high energy-resolution detectors (van der Ent et al. 2018; Montanha et al. 2020b) and portable XRF systems enabled to assess plant specimens under in vivo and in situ conditions (Montanha et al. 2020b; Montanha et al. 2020c; Mijovilovich et al. 2020; Soares et al. 2021; Corrêa et al. 2021), thereby providing means for tracking ever-changing physiological processes, e.g., the absorption of nutrients and pollutants through roots and leaves, and their movement toward tissues while they are taking place (van der Ent et al. 2018; da Cruz et al. 2019; Montanha et al. 2020b; Montanha et al. 2020c).

XRF is often regarded as a non-destructive tool. Nevertheless, X-ray beam-induced radiation damage is a critical issue for the in vivo X-ray analysis of biological samples. In principle, the X-ray ionizing feature can affect either the composition or structure of the materials, thereby producing artefacts that might result in biased results (Smith et al. 2009; Matsushima et al. 2013; Terzano et al. 2013). X-ray radiation can lead to cell damage, decrease the photosynthetic activity (Matsushima et al. 2013), photoreduction of elements (Smith et al. 2009), changes in element distribution and breaking of chemical bonds, thus, also altering the chemical speciation (Terzano et al. 2013). The type and extent of radiation damage mainly depend on the inherent characteristics of the samples, e.g., chemical composition and state, and the analysis conditions such as the beam energy, flux density, and the measurement's dwell time (Vijayan et al. 2015).

The existence of radiation damage is a welldocumented issue during XRF analysis of plants, especially on those carried out on synchrotron sources (Ellis et al. 1998; Freeman 2006; A. Castillo-Michel et al. 2016; Jones et al. 2017; Gomes et al. 2019). On the other hand, it also poses an issue with laboratory devices (van der Ent et al. 2018; Jones et al. 2019), e.g., X-ray radiation-induced damage was found on Arabidopsis thaliana leaves subjected to in vivo XRF mapping in a house-made $\mu$-XRF spectrometer furnished with $\mathrm{Rh}$ anode $(50 \mathrm{~W}, 50 \mathrm{kV} 1 \mathrm{~mA})$ and focused X-ray beam of $23.7 \mu \mathrm{m}$ FWHM at WL3 edge (Fittschen et al. 2017). These studies focused on characterising the changes in the elemental composition as a function of X-ray exposure. However, it is still unclear whether the X-ray induced stress also leads to plants' physiological responses.

In this scenario, the present study systematically investigated the effects of X-ray irradiation on soybean (Glycine max (L.) Merrill) leaves. Besides monitoring the redistribution of elements during the X-ray irradiation, the effects on tissue morphology and biochemistry were also investigated to provide a comprehensive overview of the plant's response to XRF analyses. 


\section{MATERIALS AND METHODS}

\section{Plant materials and cultivation}

The experiments were carried out using soybean plants (Glycine $\max (\mathrm{L}$.$) Merrill) at the V3 growth stage, i.e., when$ the second trifoliate leaf was completely expanded. The soy seeds (M7739 IPRO variety, Monsoy, Brazil) were sowed in plastic pots containing a moistened sandy substrate and irrigated with deionized water during the first seven days, and thereupon, with 1:5 Arnon's and Hoagland hydroponic solution (Hoagland and Arnon 1950) until the plants reached the V3 growth stage. The cultivation took place in a growth room under a $12 \mathrm{~h}$-photoperiod at $250 \mu \mathrm{mol}$ of photons $\mathrm{m}^{-2} \mathrm{~s}^{-1}$ and $27 \pm 2{ }^{\circ} \mathrm{C}$. Each experiment herein described was carried using at least two independent biological replicates.

\section{In vivo $X$-ray radiation exposure assays}

The irradiation assays were conducted on the cotyledonary leaves. The soybean plants were transferred to an acrylic sample holder conserving the substrate, with the leaves fixed with Kapton tape on the top of a $5 \mu \mathrm{m}$ polypropylene film (Spex SamplePrep, no. 3520, USA) and loaded into a benchtop microprobe X-ray fluorescence equipment ( $\mu-\mathrm{XRF}$, Orbis PC EDAX, USA). Figure S1 details the setup assembled for conducting the experiments. The $\mu-\mathrm{XRF}$ equipment is furnished with a $50 \mathrm{~W} \mathrm{Rh} \mathrm{X}$-ray tube at $17.44 \mathrm{keV}$ Mo-K $\alpha$ energy yielding either a $1 \mathrm{~mm}$ collimated X-ray beam (hereby referred to as "low photon flux"), or a $30 \mu \mathrm{m}$ polycapillaryfocused beam (hereby referred to as "high photon flux"). Spectra were recorded at 2 to 4 min intervals for longer studies, and $3 \mathrm{~s}$ intervals for the shorter studies. Additional tests were conducted using a $25-\mu \mathrm{m}$ thick Ti primary filter to enable Mn detection. The spectra were recorded by a $30 \mathrm{~mm}^{2}$ silicon drift detector with a deadtime below 10\%. The elemental signals were distinguished from the background using their threshold values ( $\mathrm{T})$, calculated according to equation 1 ;

$$
\text { Equation 01. } T=6 \cdot \sqrt{\frac{2 \overline{B G}}{t}}
$$

Where: $\overline{B G}$ (cps) is the average of 10 random measurements of background count rate under the corresponding analyte signal, t (s) is the acquisition time (Jenkins 1995; Kadachi and Al-Eshaikh 2012).

\section{XRF elemental characterization of the irradiated plant tissues}

Fresh and dried samples were irradiated for 20 min with a high photon flux before being left at rest for 24 hours. The leaf segments were then mapped under vivo conditions, detached and dried in a laboratory oven at $60{ }^{\circ} \mathrm{C}$ for $48-\mathrm{h}$, and reanalysed under the same conditions. The irradiated areas were mapped within a 32 x 25-pixel matrix and scanned along a 32-point line using the benchtop $\mu$-XRF instrument. Both analyses were carried out by employing a $30 \mu \mathrm{m} X$-ray beam generated by an $\mathrm{Rh} \mathrm{X}$-ray tube at $40 \mathrm{kV}$ and $500 \mu \mathrm{A}$, with a $25 \mu \mathrm{m}$-thin Ti primary filter selected. The dwell time was $3 \mathrm{~s}$ for the maps and $10 \mathrm{~s}$ for the linescans, respectively.

\section{Histochemical characterisation of irradiated plant tissues}

To verify whether radiation damage induces physiological changes in the irradiated area, soybean leaves were irradiated for 2 or $240 \mathrm{~s}$ with high photon flux. Following irradiation, one group of leaves were detached from the petiole 2 or $24 \mathrm{~h}$ past the irradiation and imaged using a digital microscope (Hirox, KH-8700, Japan), whereas another group was subjected to histochemical assays to verify the occurrence of $\mathrm{H}_{2} \mathrm{O}_{2}$ through immersion in a 3,3'-diaminobenzidine (DAB) staining solution [1 $\mathrm{mg}$ $\mathrm{mL}^{-1} \mathrm{DAB}$, Tween $20(0.05 \% \mathrm{v} / \mathrm{v})$ and $10 \mathrm{mM} \mathrm{Na} 2 \mathrm{HPO} 4$, $\mathrm{pH}>6.8$ ] for $2-4 \mathrm{~h}$, according to the method previously described (Daudi and O'Brien 2012); callose (1,3- $\beta$-Glucan) by staining with an aniline blue $(0.01 \% \mathrm{v} / \mathrm{v}$ in phosphate buffer, $\mathrm{pH}$ 7.2) solution (Brandizzi 2000) for $20 \mathrm{~min}$; and autophagic vacuoles through staining using a monododecyl cadaverine (MDC, $0.001 \mathrm{~mol} \mathrm{~L}^{-1}$ in phosphate buffer) solution for 30 minutes (Contento et al. 2005; Kabbage et al. 2013). In all tests, the leaf samples were directly mounted on the glass slides containing PBS buffer and analysed through an autofluorescence light microscope (Zeiss, Axion Observer, Germany). The fluorescent images were taken using a filter set (excitation: $365 \mathrm{~nm}$; emission: $420 \mathrm{~nm}$ ), which was also employed to detect chlorophyll autofluorescence (Donaldson 2020).

\section{Anatomical characterisation of irradiated plant tissues}

A $c a .3 \mathrm{~mm}^{2}$ piece of the leaf samples irradiated for $240 \mathrm{~s}$ at high photon flux were harvested 24 after the exposure, then fixed in Karnovsky's solution (Karnovsky 1965), dehydrated in an increasing ethanolic series, embedded in historesin, sequentially cross-sectioned in a rotatory microtome, and stained with toluidine blue (TBO, SigmaAldrich, Germany), according to the method described elsewhere (Marques et al. 2015). The samples were then mounted on glass slides containing synthetic resin (Entelan ${ }^{\circledR}$, Sigma-Aldrich, Germany). The images were taken using a microscope (Zeiss, Axion Observer, Germany).

\section{Transmission electron microscopy structural characterization of irradiated plant tissues}

Following X-ray exposure, the leaves irradiated for 24 min and $10 \mathrm{~s}$ with high photon flux were harvested and immediately immersed in a Karnovsky's fixing solution (Karnovsky 1965), then post-fixed in $1 \% \mathrm{v} / \mathrm{v}$ osmium tetroxide $+0.1 \mathrm{~mol} \mathrm{~L}^{-1}$ cacodylate buffer $(\mathrm{pH} 7.2)$. The samples were washed thrice in a cacodylate buffer and transferred to a $0.5 \% \mathrm{v} / \mathrm{v}$ uranyl acetate solution overnight. Thereafter, the leaf samples were washed thrice in water and dehydrated in ketone series $(30 \%, 50 \%, 70 \%, 90 \%$, and $100 \%$, twice) for 15 minutes (Marques and Soares 2021) and embedded in Spurr resin (Sigma-Aldrich, Germany) with the standard formulae. The blocks were then cut in an ultramicrotome (UC6, Leica, Germany) and the ultrathin sections were stained with $5 \%$ v/v uranyl acetate and lead $2 \% \mathrm{v} / \mathrm{v}$ citrate for $15 \mathrm{~min}$ each (Reynolds 1963). The samples were analysed under transmission electron microscopy (TEM 1011, JEOL, Japan). The elemental, histochemical, anatomical, and ultrastructural characterization of irradiated leaf tissues are summarised in 


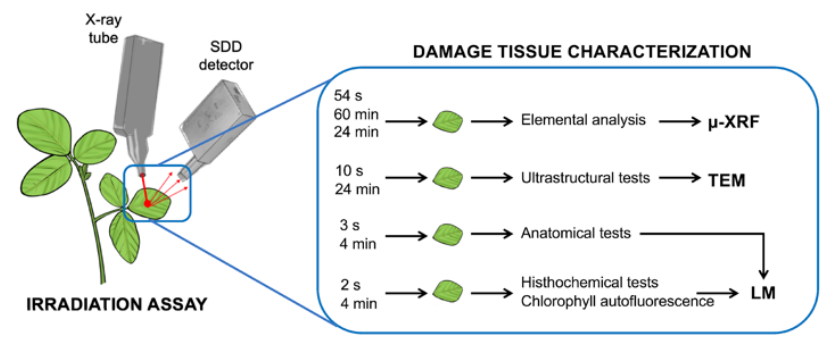

Fig. 1.

FIg. 1. Scheme of the experimental workflow for the elemental, histochemical, anatomical, and ultrastructural characterization of irradiated soybean leaf tissues. Samples irradiated for $2 \mathrm{~s}$ and $4 \mathrm{~min}$ were subjected to histochemical and anatomical tests and analysed with light microscopy (LM) while samples irradiated for $10 \mathrm{~s}$ and 24 min were subjected to ultrastructural tests with TEM and $\mathrm{u}-\mathrm{XRF}$.

\section{RESULTS}
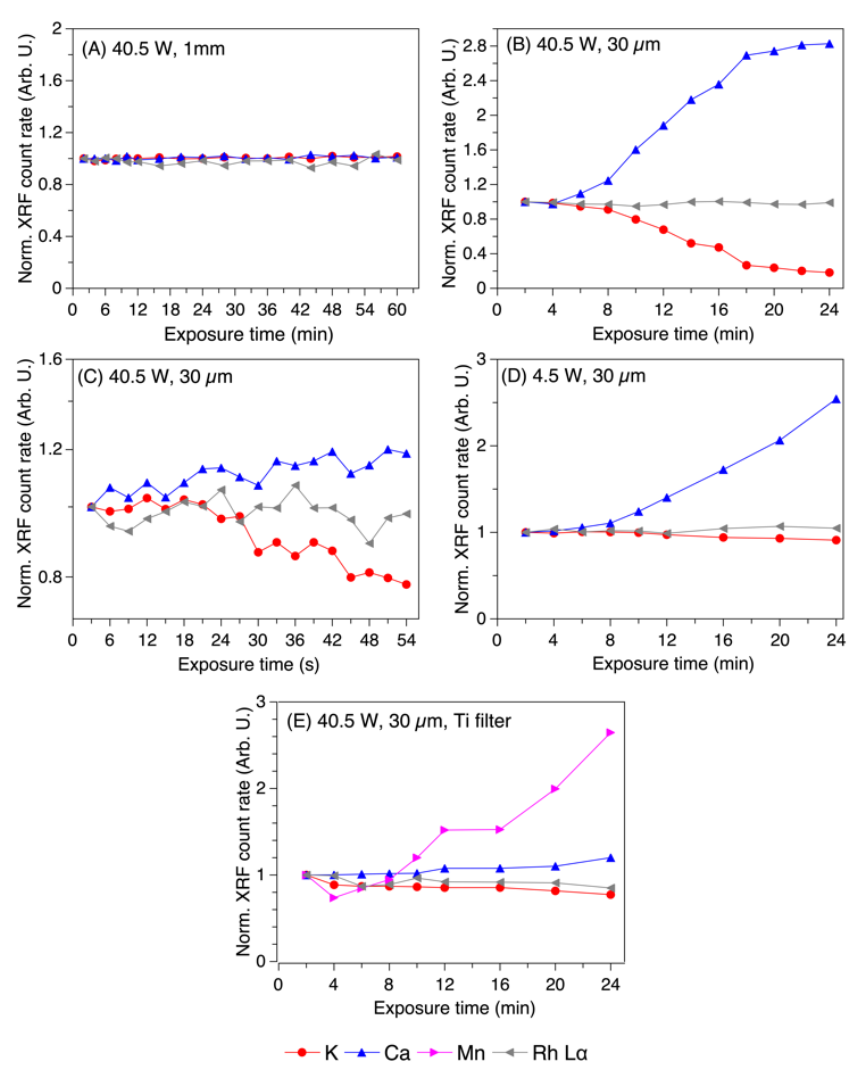

\section{Elemental changes on irradiated soybean tissues}

FIg. 2. Normalized XRF $\mathrm{K}, \mathrm{Ca}$, and $\mathrm{Rh} \mathrm{L} \alpha$ count rate recorded on soybean leaves at V3 growth stage as a function of the exposure time (54 s, 24-60 min) to a collimated $1 \mathrm{~mm}$ or polycapillary focused $30 \mu \mathrm{m}$ X-ray beam derived from an $\mathrm{Rh}$ anode at $40.5 \mathrm{~W}(45 \mathrm{kV}$ and $900 \mu \mathrm{A}, \mathrm{A}-\mathrm{C})$ or 4.5 power $(45 \mathrm{kV}$ and $100 \mu \mathrm{A}, \mathrm{D})$, without (A-D) or with a $25-\mu \mathrm{m}$ thick Ti primary filter selected (E). The intensities were normalized by their respectively first recorded values. Only 24 of the 60-min of irradiation are shown in B and E to ease data visualization.

Figure 2A-D shows the XRF signals for the K-alpha peaks of $\mathrm{P}, \mathrm{K}$, and $\mathrm{Ca}$, as well as the $\mathrm{Rh} \mathrm{L} \alpha$ scattering recorded in living soybean leaves exposed at four different X-ray conditions. These results reveal that the low photon flux (Fig. 2A) does not alter the intensities of the detected elements.
However, one should keep in mind that a high photon flux beam is used for generating elemental maps. Under these conditions, one can notice that the effects of radiation damage is significant over the course of $24 \mathrm{~min}$ (Fig. 2B), with the onset of damage occurring in less than a minute (Fig. 2C). The general trend is a decrease in $\mathrm{K}$ and an increase in $\mathrm{Ca}$, suggesting that the $\mathrm{K}$ is being removed from the damaged region while $\mathrm{Ca}$ is being accumulated. Reducing the power by an order of magnitude to $4.5 \mathrm{~W}$ (Fig. 2D) shows a similar trend as those observed in the exposures at $40.5 \mathrm{~W}$, albeit at a slightly slower rate. In all cases, the Rh La scattering did not present any clear pattern of change, suggesting the damage observed is not mass loss (Jones et al. 2019). Employing a Ti filter enabled the detection of Mn, showing a sharp increase as a function of the exposure time (Fig. 2E). Figure S2 presents the same trend obtained on independent biological replicates. In addition, Fig. S3 shows elemental composition modification induced by $24 \mathrm{~min}$ irradiation under the $40.5 \mathrm{~W}$ focused beam were not reversible after two hours of plant rest. In other words, the tissue was not able to recover itself during this time interval.

To distinguish the modifications induced by the X-ray beam from those caused by dehydration, the elemental composition of fresh and $48 \mathrm{~h}$ oven-dried soy leaves irradiated with the high photon flux were imaged by $\mu$-XRF, presented in Fig. 3. The photographs of the soybean leaf tissues in both cases reveal visual signs of necrosis (dark spot) in the irradiated region 24-h after the X-ray exposure. The chemical maps, in line with the time-resolved exposure (Fig. 2), shows a sharp decrease in $\mathrm{K}$ and an increased $\mathrm{Ca}$ intensity in the irradiated spots. Similarly, the Mn count rate is $c a$. 10 to 50-fold higher in the irradiated regions compared to its neighbouring regions. This is highlighted in the linescans, which provides a higher lateral resolution than the maps. The same trend is observed on the 48-h oven-dried leaves (Fig. 3B), thus, under the available lateral resolution, the tissue drying did not influence the elemental spatial distribution. Therefore, we do not suspect that radiationinduced dehydration is responsible for the trends observed. The same trend was recorded on independent biological replicates presented in Fig. S4. On the other hand, no damage was observed for a $10 \mathrm{~s}$ exposure, as expected from data presented in Fig. 2D and Fig. S4.

\section{$X$-ray induced anatomical, histochemical and ultrastructural changes on soybean leaf tissues}

A series of plant anatomy techniques, i.e., anatomical, ultrastructural, and histochemical, assays were herein explored to properly determine which factors have taken a role in the observed X-ray induced damage presented in Fig. 2 and Fig. 3.

Comparing the anatomical patterns of the irradiated leaf tissues, i.e., exposed to $10 \mathrm{~s}$ (Fig. 4A-F) or $20 \mathrm{~min}$ (Fig. 4G$\mathrm{O})$ to the high photon flux beam, and the non-irradiated tissues, one cannot observe any damage in those regions irradiated for $10 \mathrm{~s}$. These leaflets present a single lensshaped epidermal cell layer with a thin-cuticle (Fig. 4A-E), as well as a dorsiventral mesophyll with 1-2 palisade parenchyma cells and 4 to 5 layers of spongy parenchyma (Fig. 4B) cells with a high number of chloroplasts with starch (Figure 4F). The vascular bundle is collateral and present a leaf sheath extension (Fig. 4A). 
bioRxiv preprint doi: https://doi.org/10.1101/2022.01.18.476760; this version posted January 20, 2022. The copyright holder for this preprint (which was not certified by peer review) is the author/funder, who has granted bioRxiv a license to display the preprint in perpetuity. It is made available under aCC-BY-NC-ND 4.0 International license.
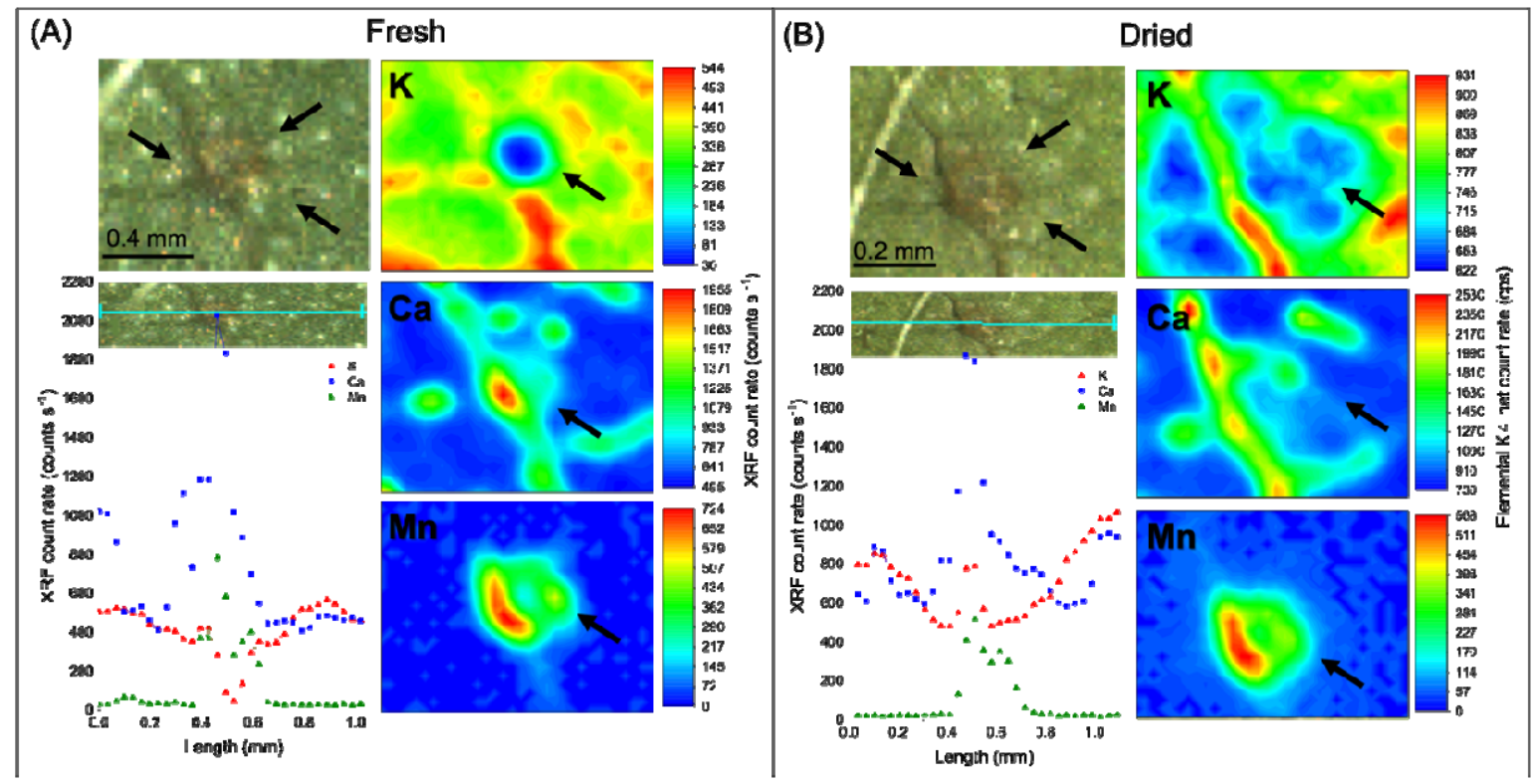

FIg. 3. Photographs and XRF probing of K, Ca, and Mn spatial distribution on fresh (A) and dried (B) soybean leaves at V3 growth stage exposed to polycapillary focused $30 \mu \mathrm{m} \mathrm{X-ray} \mathrm{beam} \mathrm{at} 40.5 \mathrm{~W}(45 \mathrm{kV}$ and $900 \mu \mathrm{A})$ for 20 minutes. An 800-pixel XRF map and a 32-point XRF linescan were carried out in each case. The fresh leaves were monitored $24 \mathrm{~h}$ past the irradiation, then oven-dried at $60^{\circ} \mathrm{C}$ for $48 \mathrm{~h}$ and reanalysed at the same instrumental conditions. The black arrows denote the irradiated regions, where a necrotic spot and clear changes on the elemental distribution in both fresh and dried leaf tissues is observed.
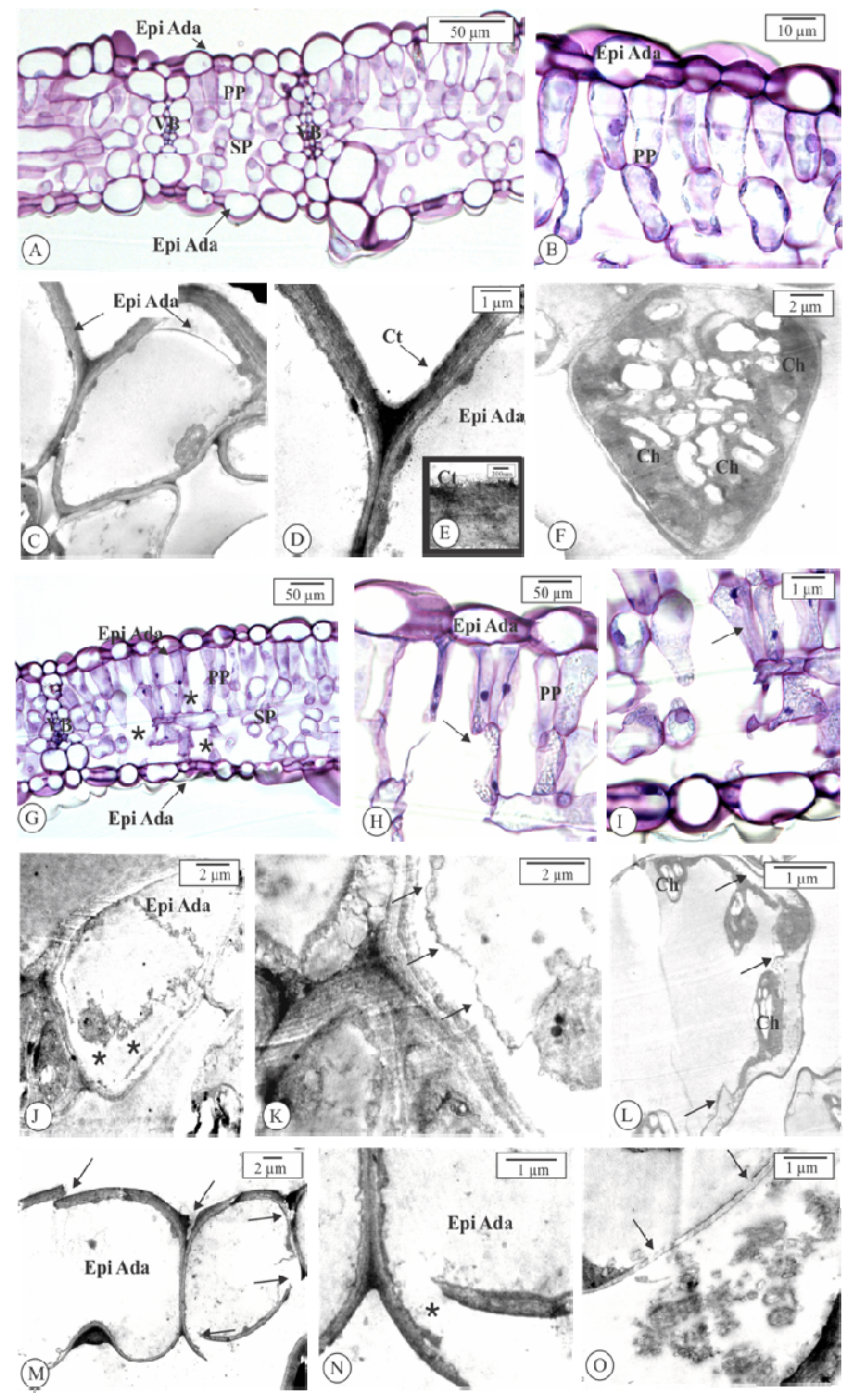

(O)
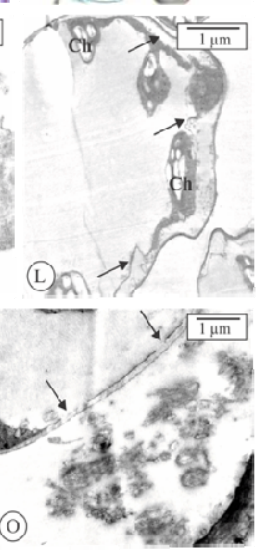

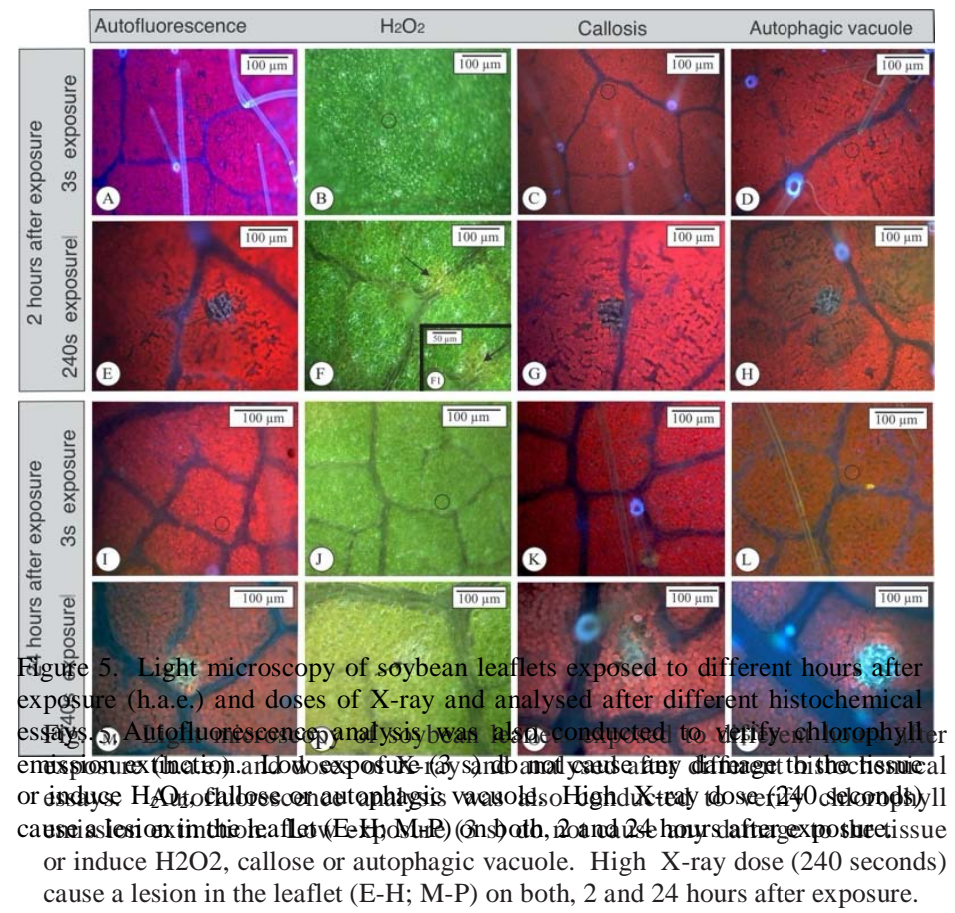

Fig. 4. Light and electron micrographs of regions of soybean leaflets at V4 growth stage irradiated for $10 \mathrm{~s}(\mathrm{~A}-\mathrm{F})$ and $20 \mathrm{~min}(\mathrm{G}-\mathrm{O})$ with $30 \mu \mathrm{m}$ focus generated by a Rh anode with $40.5 \mathrm{~W}$ of power $(45 \mathrm{kV}$ and $900 \mu \mathrm{A})$. The anatomy of the $10 \mathrm{~s}$ irradiated tissues remains healthy, indicating Epidermal cells are lens-shaped and covered by a thin cuticle (A-E). F. Spongy parenchyma cell with chloroplasts. The $20 \mathrm{~min}$ irradiated tissues (G-O) shows injured regions (* in G). The lesion promotes cells wall rupture (arrows H; I; M$\mathrm{N})$. Cell plasmolysis of the leaf and plasm membrane detachment were observed (* in J and arrows in K-L). M. Protoplast leaking in the intercellular space. $\mathrm{Ch}$ - chloroplast;

$\mathrm{Ct}$ - cuticle; Epi Ada - epidermis adaxial; $\mathrm{Pp}$ - palisade parenchyma; $\mathrm{Sp}$ - spongy Parenchyma; $\mathrm{Vb}$ - vascular bundle.

Conversely, the damage is observed in the epidermis and mesophyll cells of the leaves irradiated for $20 \mathrm{~min}$. The 
damaged region encompasses a $c a .100 \mu \mathrm{m}$ area, more than three-fold larger than the putative $30 \mu \mathrm{m} X$-ray beam spot size (Fig. 4G). The TEM images revealed the rupture of cellwalls in the mesophyll and epidermal cells (Fig. 4H-I; L-N), as well as plasmolysis, i.e., the detachment of the plasm membrane (Fig. 4J-K), and the leakage of the cytoplasm to the extracellular region (Fig. 40).

Furthermore, the histochemical tests conducted on soybean leaves either 2 or 24 hours after the exposure (h.a.e) to the high photon flux beam during 2 or $240 \mathrm{~s}$ (Fig. 5) unveiled that regardless of the recovery time, the $2 \mathrm{~s}$ X-ray shots neither impaired the chlorophyll autofluorescence nor induced detectable production of $\mathrm{H}_{2} \mathrm{O}_{2}$, callose, or autophagic vacuoles (Fig. 5 A-D; I-L), whereas extinction of chlorophyll autofluorescence (Fig. $5 \mathrm{E} ; \mathrm{M}$ ), as well as a positive reaction with both aniline blue and monododecyl cadaverine reagents, were recorded for the $240 \mathrm{~s}$ shots, depicting the development of callose and the autophagic vacuoles (Fig. 5G;O and Fig. 5H-P). Oddly, although the positive diaminobenzidine (DAB) reaction confirms the $\mathrm{H}_{2} \mathrm{O}_{2}$ accumulation in the high photon flux irradiated area 2 h.a.e (Fig. 5F-F1), it was not detected 24 h.a.e. (Fig. 5N) suggesting that the induced damages hampered the cells redox metabolism, thus, their ability in producing ROS.

\section{DISCUSSION}

One of the main analytical advantages of X-ray fluorescence spectroscopy is the ability to interrogate the elemental composition and distribution of biological materials on their steady states ( Montanha et al. 2020b; Montanha et al. 2020c; Pushie et al. 2020), with minimal or even no sample preparation requirements (Rodrigues et al. 2018; Montanha et al. 2020b). From a botanical standpoint, the in vivo and in situ XRF-based analysis of plant tissues encompass a unique opportunity to elucidate key mechanisms on plants physiology, such as root-to-shot and foliar nutrient uptake (Gomes et al. 2019; Montanha et al. 2020b; Montanha et al. 2020c; Corrêa et al. 2021), metal hyperaccumulation (Hernandez-Viezcas et al. 2013; van der Ent et al. 2018) and toxicity (Reis et al. 2020; Lanza et al. 2021), and changes in elemental distribution in healthy and injured tissues (Marques et al. 2020; Macedo et al. 2021; Naim et al. 2021).

Nonetheless, the X-ray beam-induced radiation damage is a major issue for the in vivo XRF measurements of biological materials, since the ionising nature of the X-rays can alter both the composition and structure of the samples, producing artefacts that might severely impact the driven results (Smith et al. 2009; Matsushima et al. 2013; Terzano et al. 2013). X-ray induced damage mainly depends on the dose, i.e., the amount of radiation deposited in a certain volume, which is as a function of the incident photon flux intensity, samples' X-ray mass attenuation coefficient, and the exposure time (Oger et al. 2008; Jones et al. 2017, 2019). This is highlighted in our irradiation experiments (Fig. 2), which clearly showed that the higher the dose, the higher the changes in the elemental signals of an irradiated spot. We note that the X-ray tube was kept constant at $45 \mathrm{kV}$ in our experiments, and the doses were modulated through the use of the photon flux current, exposure time, presence or absence of a primary filter, and the use or not of focusing optics.
A sharp decrease of $\mathrm{K}$ and an increase of Ca signals were detected whenever employing the polycapillary $30 \mu \mathrm{m}$ beam (Fig. 2B-E). These findings are quite similar to those results reported in our previous studies (Jones et al. 2019; Montanha et al. 2020c). Furthermore, the $25 \mu \mathrm{m}$-thick Ti primary filter enabled us to record a remarkable increase of Mn signals due to the reduction of the background radiation reaching the $\mathrm{X}$ ray detector. However, the use of this filter between the $\mathrm{X}$ ray source and the sample also reduces the photon flux, thereby leading to less extensive changes in the elemental composition for a given exposure time. This phenomenon is illustrated in Fig. S7, which presents the XRF recorded on a Plexiglas cube with and without the $25 \mu \mathrm{m}$-thick Ti primary filter selected. We note that due to the reduced flux, elemental sensitivity is also reduced, and longer exposure times would be required to achieve the same signal as without the filter for elements apart from Mn.

Although it seems that plant materials are prone to tissue dehydration caused by the heating during beam exposure either at a synchrotron facility or laboratory-based XRF equipment, directly interfering with elemental distribution and chemical speciation (Tylko et al. 2007; Lombi et al. 2011), it is important to highlight that the Rh-La scattering peaks, highly sensitive to the samples total mass and therefore dehydration (Bastos et al. 2012), was only slightly affected by the X-ray exposure in our assays (Fig. 1). Therefore, dehydration might not be the only, or major, contributing factor to the elemental changes recorded. The elemental maps of the irradiated areas of fresh and dried tissues (Fig. 3) reinforce this hypothesis, since both $\mathrm{K}, \mathrm{Ca}$, Mn distribution pattern remains after sample drying.

Additionally, since the observed changes were not reversible (Fig. 3, S2-S3), they might likely be related to plant response to the acute stress induced by the X-ray exposure. For example, increased $\mathrm{Ca}$ and $\mathrm{Mn}$ contents have been observed on wheat leaves inoculated with a fungal pathogen (Naim et al. 2021).

The anatomical and ultrastructural analyses revealed that the damaged area encompasses a spot $c a$. 3-fold higher than the $30 \mu \mathrm{m}$ beam at Mo K-alpha energy (Fig. 4). Although the incident beam herein explored was not a monochromatic one, longer wavelengths result in larger beams. However, this does not account for the extent of the damaged region. Moreover, the histochemical assay with DAB indicated the presence of $\mathrm{H}_{2} \mathrm{O}_{2}$ (Fig. 5B; F; J; N), a key reactive oxygen species (ROS) on plant physiology (Quan et al. 2008), $2 \mathrm{~h}$ past the $20 \mathrm{~min}$ irradiation with the high photon flux, unveiling a localised molecular response to a stressful condition. Interestingly, one should notice that $\mathrm{Mn}$ is a cofactor of the Mn-superoxide dismutase, a crucial enzyme in the redox metabolism of plants (Morgan et al. 2008), whereas $\mathrm{Ca}$ is a well-known marker of abiotic stress in plants (WHITE and BROADLEY 2003; Toyota et al. 2018). It does suggest that the increasing $\mathrm{Ca}$ and $\mathrm{Mn}$ signals recorded during the irradiation might reflect both stress-like signalling and demand for enzymes for ROS scavenging processes. Moreover, although the presence of callose ( $\beta$-1,3-glucan), a cell-wall polysaccharide strongly related to biotic and abiotic stress signalling (Chen and Kim 2009; Zavaliev et al. 2011), was not observed in the stress. Moreover, autophagic vacuoles are a specialised group of organelles holding hydrolytic-like enzymes related to cell digestion which plays crucial roles in programmed cell death (PCD) processes 
(Floyd et al. 2015) was also not verified This suggests that the $20 \mathrm{~min} \mathrm{X}$-ray exposure was able to destroy soybean leaf tissues even before callose outbreak and autophagic vacuoles production, as emphasized by the cell wall ruptures, plasmolysis and protoplast leaking (Fig. 4).

Finally, the characterisation herein presented reveals that a significant fraction of the elemental changes as a function of X-ray beam exposure stem from plants' physiological signalling or response, and not simply from sample dehydration, as previously suggested. These response mechanisms are illustrated in the schematic representation shown in Fig. 6. Nevertheless, one should keep in mind that these effects are dose-dependent, and therefore, all studies employing X-ray or other radiation-based methodologies for biological samples are encouraged to include a preliminary investigation to verify if beam damage is interfering in the reliability of the data, and, if necessary, take the appropriate decision to overcome radiation artefacts.

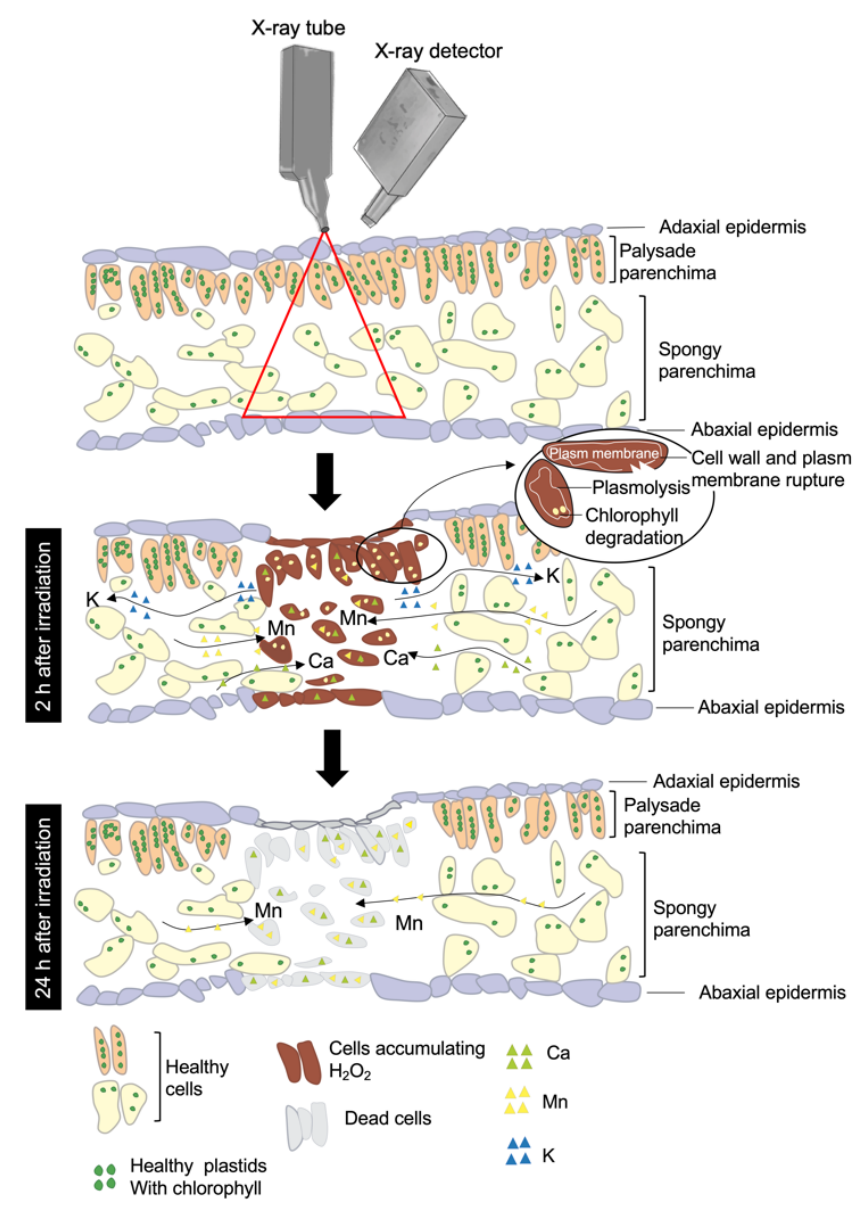

Fig. 6. Time-resolved effects of high-doses X-ray exposure on soybean leaf tissues. During the first 2 hours after the exposure, the X-ray irradiation induces chlorophyll degradation, plasmolysis, and rupture of the cell walls and plasm membrane, thereby leading to K efflux, ROS accumulation and $\mathrm{Ca}$ and $\mathrm{Mn}$ increasing in the irradiated cells. However, most of the irradiated cells die 24 hours after exposure.
We thank the Laboratory of Electron Microscopy "Prof. Elliot Watanabe Kitajima" at the Luiz de Queiroz College of Agriculture of the University of São Paulo for providing the infrastructure for the microscopy analysis, as well as Dr. Eduardo de Almeida for his valuable comments during the conduction of this work.

\section{FUNDING}

This work was supported by São Paulo Research Foundation (grants 2015/ 2020/07721-9 to G.S.M; 2020/11546-8 to E.S.R; 2015/19121-8 to H.W.P.C.) and the Brazilian National Council for Scientific and Technological Development (CNPq) (grant 306185/2020-2 to H.W.P.C.)

\section{DATA AVAILABILITY}

The raw data herein presented is fully available at Figshare repository: https://doi.org/10.6084/m9.figshare.18584384.v1

\section{LITERATURE CITED}

A. Castillo-Michel H, G. Diaz-Sanchez A, MartinezMartinez A, Hesse B. 2016. Investigations of Sulfur Chemical Status with Synchrotron Micro Focused X-ray fluorescence and X-ray Absorption Spectroscopy. Protein \& Peptide Letters 23: 291-299.

Bastos RO, Melquiades FL, Biasi GE V. 2012. Correction for the effect of soil moisture on in situ XRF analysis using low-energy background. X-Ray Spectrometry 41: 304-307.

Brandizzi F. 2000. Ruzin SE. 1999. Plant microtechnique and microscopy. 322 pp. Oxford, New York: Oxford University Press. $£ 32.50$ (softback). . Annals of Botany 86: 708.

Chen X-Y, Kim J-Y. 2009. Callose synthesis in higher plants. Plant Signaling \& Behavior 4: 489-492.

Contento AL, Xiong Y, Bassham DC. 2005. Visualization of autophagy in Arabidopsis using the fluorescent dye monodansylcadaverine and a GFP-AtATG8e fusion protein. The Plant Journal 42: 598-608.

Corrêa CG, Rebouças MT, Diniz M, Pereira de Carvalho HW. 2021. Effect of Counterions on the Foliar Absorption and Transport of Potassium in Soybeans [Glycine max (L.) Merrill]. ACS Agricultural Science \& Technology 1: 728734.

da Cruz TNM, Savassa SM, Montanha GS, et al. 2019. A new glance on root-to-shoot in vivo zinc transport and timedependent physiological effects of $\mathrm{ZnSO}<\mathrm{inf}>4</ \mathrm{inf}>$ and $\mathrm{ZnO}$ nanoparticles on plants. Scientific Reports 9.

Daudi A, O'Brien JA. 2012. Detection of Hydrogen Peroxide by DAB Staining in Arabidopsis Leaves. Bioprotocol 2: e263.

Donaldson L. 2020. Autofluorescence in Plants. Molecules 25.

Ellis AT, Holmes M, Kregsamer P, et al. 1998. Atomic Spectrometry Update-X-ray Fluorescence Spectrometry. Journal of Analytical Atomic Spectrometry 13: 209R-232R.

Fittschen UEA, Kunz H $\square$ H., Höhner R, Tyssebotn IMB, Fittschen A. 2017. A new micro $X \square$ ray fluorescence 
spectrometer for in vivo elemental analysis in plants. $X \square R a y$ Spectrometry 46: 374-381.

Floyd BE, Pu Y, Soto-Burgos J, Bassham DC. 2015. To Live or Die: Autophagy in Plants BT - Plant Programmed Cell Death In: Gunawardena AN, McCabe PF, eds. Cham: Springer International Publishing, 269-300.

Freeman JL. 2006. Spatial Imaging, Speciation, and Quantification of Selenium in the Hyperaccumulator Plants Astragalus bisulcatus and Stanleya pinnata. Plant Physiology.

Gomes MHF, Machado BA, Rodrigues ES, et al. 2019. In Vivo Evaluation of $\mathrm{Zn}$ Foliar Uptake and Transport in Soybean Using X-ray Absorption and Fluorescence Spectroscopy. Journal of Agricultural and Food Chemistry 67.

Hernandez-Viezcas JA, Castillo-Michel H, Andrews JC, et al. 2013. In situ synchrotron $\mathrm{X}$-ray fluorescence mapping and speciation of $\mathrm{CeO} 2$ and $\mathrm{ZnO}$ nanoparticles in soil cultivated soybean (Glycine max). ACS Nano 7: 1415-1423.

Hoagland DR, Arnon DI. 1950. The water-culture method for growing plants without soil. Circular. California Agricultural Experiment Station.

Jenkins R. 1995. Quantitative X-ray spectrometry. CRC Press.

Jones MWM, Hare DJ, James SA, de Jonge MD, McColl G. 2017. Radiation Dose Limits for Bioanalytical X-ray Fluorescence Microscopy. Analytical Chemistry 89: 1216812175.

Jones MWM, Kopittke PM, Casey L, Reinhardt J, Blamey FPC, van der Ent A. 2019. Assessing radiation dose limits for X-ray fluorescence microscopy analysis of plant specimens. Annals of Botany 125: 599-610.

Kabbage M, Williams B, Dickman MB. 2013. Cell Death Control: The Interplay of Apoptosis and Autophagy in the Pathogenicity of Sclerotinia sclerotiorum. PLOS Pathogens 9: e1003287.

Kadachi AN, Al-Eshaikh MA. 2012. Limits of detection in XRF spectroscopy. X-Ray Spectrometry 41: 350-354.

Karnovsky JM. 1965. A formaldehyde-glutaraldehyde fixative of high osmolality for use in electron microscopy. Journal of Cell Biology.

Lanza MGDB, Silva VM, Montanha GS, Lavres J, Pereira de Carvalho HW, Reis AR dos. 2021. Assessment of selenium spatial distribution using $\mu$-XFR in cowpea (Vigna unguiculata (L.) Walp.) plants: Integration of physiological and biochemical responses. Ecotoxicology and Environmental Safety 207: 111216.

Lau E, Bragança Carvalho L, Espirito Santo Pereira A, et al. 2020. Localization of Coated Iron Oxide (Fe3O4) Nanoparticles on Tomato Seeds and their Effects on Growth. ACS Applied Bio Materials.

Lombi E, de Jonge MD, Donner E, et al. 2011. Fast X-Ray Fluorescence Microtomography of Hydrated Biological Samples. PLOS ONE 6: e20626.

Macedo FG, Montanha GS, Pereira de Carvalho HW, de Melo WJ. 2021. Nickel Influences Urease Activity and Calcium Distribution in Tomato Fruits. ACS Agricultural
Science \& Technology 1: 29-34.

Marques JPR, Amorim L, Silva-Junior GJ, Spósito MB, Appezzato-da Gloria B. 2015. Structural and biochemical characteristics of citrus flowers associated with defence against a fungal pathogen. AoB PLANTS 7: plu090.

Marques JPR, Bellato Spósito M, Amorim L, et al. 2020. Persistent Calyxes in Postbloom Fruit Drop: A Microscopy and Microanalysis Perspective. Pathogens (Basel, Switzerland) 9.

Marques JPR, Soares MKM. 2021. Manual de técnicas aplicadas à Histopatologia Vegetal (FEALQ, Ed.). Piracicaba.

Matsushima U, Graf W, Zabler S, et al. 2013. 3D-analysis of plant microstructures: advantages and limitations of synchrotron X-ray microtomography. International Agrophysics 27: 23-30.

Mijovilovich A, Morina F, Bokhari SN, Wolff T, Küpper H, Küpper H. 2020. Analysis of trace metal distribution in plants with lab-based microscopic X-ray fluorescence imaging. Plant Methods 16: 1-21.

Montanha GS, Rodrigues ES, Marques JPR, de Almeida E, Colzato M, Pereira de Carvalho, HW. 2020a. Zinc nanocoated seeds: an alternative to boost soybean seed germination and seedling development. SN Applied Sciences 2, 857

Montanha G.S., Rodrigues ES, Romeu SLZ, de Almeida E, dos Reis AR, Lavres J, Pereira de Carvalho, HW. 2020b. Zinc uptake from $\mathrm{ZnSO} 4(\mathrm{aq})$ and $\mathrm{Zn}-\mathrm{EDTA}(\mathrm{aq})$ and its root-to-shoot transport in soybean plants (Glycine max) probed by time-resolved in vivo X-ray spectroscopy. Plant Science 292.

Montanha Gabriel Sgarbiero, Rodrigues ES, Marques JPR, de Almeida E, dos Reis AR, Pereira de Carvalho HW. 2020c. X-ray fluorescence spectroscopy (XRF) applied to plant science: challenges towards in vivo analysis of plants . Metallomics.

Morgan MJ, Lehmann M, Schwarzla $\square$ nder M, et al. 2008. Decrease in Manganese Superoxide Dismutase Leads to Reduced Root Growth and Affects Tricarboxylic Acid Cycle Flux and Mitochondrial Redox Homeostasis. Plant Physiology 147: 101-114.

Naim F, Khambatta K, Sanglard LMVP, et al. 2021. Synchrotron X-ray fluorescence microscopy-enabled elemental mapping illuminates the 'battle for nutrients' between plant and pathogen. Journal of Experimental Botany 72: 2757-2768.

Oger PM, Daniel I, Simionovici A, Picard A. 2008. Micro$\mathrm{X}$-ray absorption near edge structure as a suitable probe to monitor live organisms. Spectrochimica Acta Part B: Atomic Spectroscopy 63: 512-517.

Pushie MJ, Hollings A, Reinhardt J, et al. 2020. Sample preparation with sucrose cryoprotection dramatically alters Zn distribution in the rodent hippocampus, as revealed by elemental mapping. Journal of Analytical Atomic Spectrometry 35: 2498-2508.

Quan L-J, Zhang B, Shi W-W, Li H-Y. 2008. Hydrogen Peroxide in Plants: a Versatile Molecule of the Reactive 
bioRxiv preprint doi: https://doi.org/10.1101/2022.01.18.476760; this version posted January 20, 2022. The copyright holder for this preprint (which was not certified by peer review) is the author/funder, who has granted bioRxiv a license to display the preprint in perpetuity. It is made available under aCC-BY-NC-ND 4.0 International license.

Oxygen Species Network. Journal of Integrative Plant Biology 50: 2-18.

Reis AR dos, Boleta EHM, Alves CZ, et al. 2020. Selenium toxicity in upland field-grown rice: Seed physiology responses and nutrient distribution using the $\mu$-XRF technique. Ecotoxicology and Environmental Safety 190: 110147.

Reynolds ES. 1963. THE USE OF LEAD CITRATE AT HIGH $\mathrm{pH}$ AS AN ELECTRON-OPAQUE STAIN IN ELECTRON MICROSCOPY . Journal of Cell Biology 17: 208-212.

Rodrigues ES, Gomes MHF, Duran NM, et al. 2018. Laboratory Microprobe X-Ray Fluorescence in Plant Science: Emerging Applications and Case Studies. Frontiers in Plant Science 9: 1588.

Romeu SLZ, Marques JPR, Montanha GS, de Carvalho HWP, Pereira FMV. 2021. Chemometrics unraveling nutrient dynamics during soybean seed germination. Microchemical Journal 164: 106045.

Smith E, Kempson I, Juhasz AL, Weber J, Skinner WM, Gräfe M. 2009. Localization and speciation of arsenic and trace elements in rice tissues. Chemosphere 76: 529-535.

Soares T, Wallace Pereira de Carvalho H, de Almeida E, Costa GT, Sergio Pavinato P. 2021. Phosphorus Quantification in Sugar Cane (Saccharum officinarum) Leaves In Vivo by Portable X-ray Fluorescence Spectroscopy. ACS Agricultural Science \& Technology 1: 479-487.

Terzano R, Mimmo T, Vekemans B, et al. 2013. Iron (Fe) speciation in xylem sap by XANES at a high brilliant synchrotron X-ray source: opportunities and limitations. Analytical and Bioanalytical Chemistry 405: 5411-5419.

Toyota M, Spencer D, Sawai-Toyota S, et al. 2018. Glutamate triggers long-distance, calcium-based plant defense signaling. Science 361: 1112-1115.

Tylko G, Mesjasz-Przybyłowicz J, Przybyłowicz WJ. 2007. In-vacuum micro-PIXE analysis of biological specimens in frozen-hydrated state. Nuclear Instruments and Methods in Physics Research Section B: Beam Interactions with Materials and Atoms 260: 141-148.

van der Ent A, Przybyłowicz Wojciech J., de Jonge MD, et al. 2018. X-ray elemental mapping techniques for elucidating the ecophysiology of hyperaccumulator plants. New Phytologist 218: 432-452.

Vijayan P, Willick IR, Lahlali R, Karunakaran C, Tanino KK. 2015. Synchrotron Radiation Sheds Fresh Light on Plant Research: The Use of Powerful Techniques to Probe Structure and Composition of Plants. Plant and Cell Physiology 56: 1252-1263.

White PJ, Broadley MR. 2003. Calcium in Plants. Annals of Botany 92: 487-511.

Zavaliev R, Ueki S, Epel BL, Citovsky V. 2011. Biology of callose ( $\beta$-1,3-glucan) turnover at plasmodesmata. Protoplasma 248: 117-130.
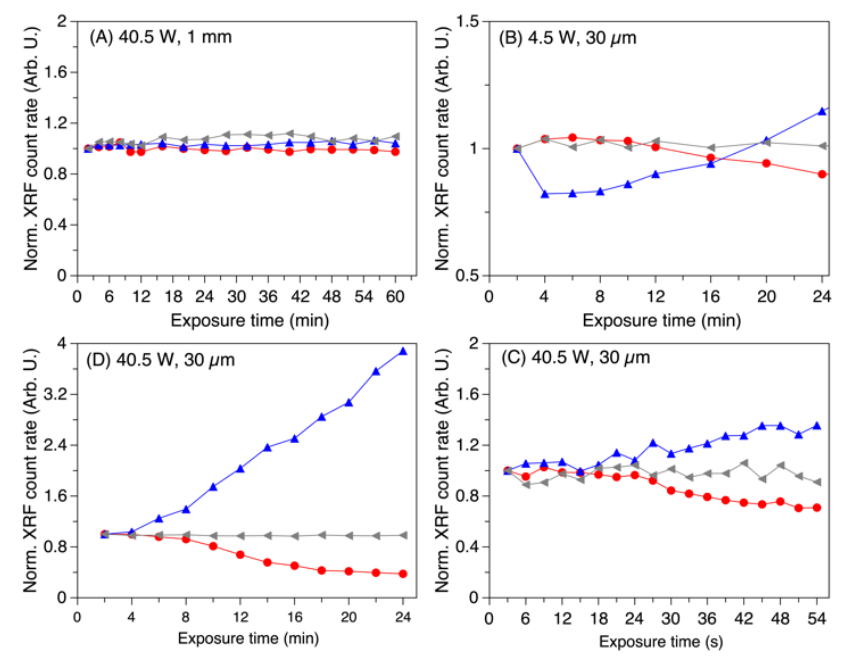

Figure S1. Setup employed for the in vivo XRF-based Xray exposure assays on soybean leaves.

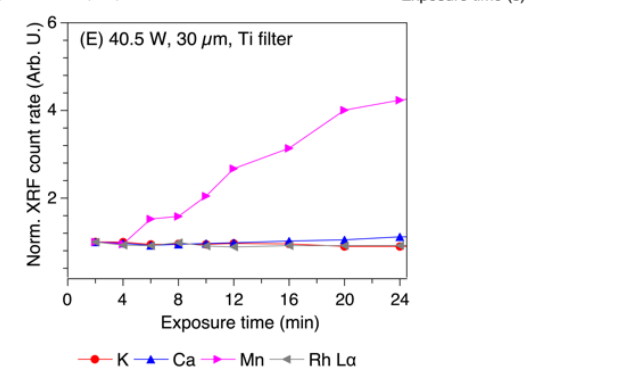

Figure S2. Normalized XRF K, Ca, and Rh L $\alpha$ count rate recorded on soybean leaves at V3 growth stage as a function of the exposure time (54 s, 24-60 $\mathrm{min})$ to a collimated $1 \mathrm{~mm}$ or polycapillary focused $30 \mu \mathrm{m}$ X-ray beam derived from an $\mathrm{Rh}$ anode at $40.5 \mathrm{~W}(45 \mathrm{kV}$ and $900 \mu \mathrm{A}, \mathrm{A}-\mathrm{C})$ or 4.5 power $(45 \mathrm{kV}$ and $100 \mu \mathrm{A}$, B-D), without or with a $25-\mu \mathrm{m}$ thick Ti primary filter selected. The intensities were normalized by their respectively first recorded values. Only the 24 of the 60-min of irradiation are shown in $\mathrm{B}$ and $\mathrm{E}$ to ease visualising the beginning of the damage. Data resulting from an independent biological 
replicate.

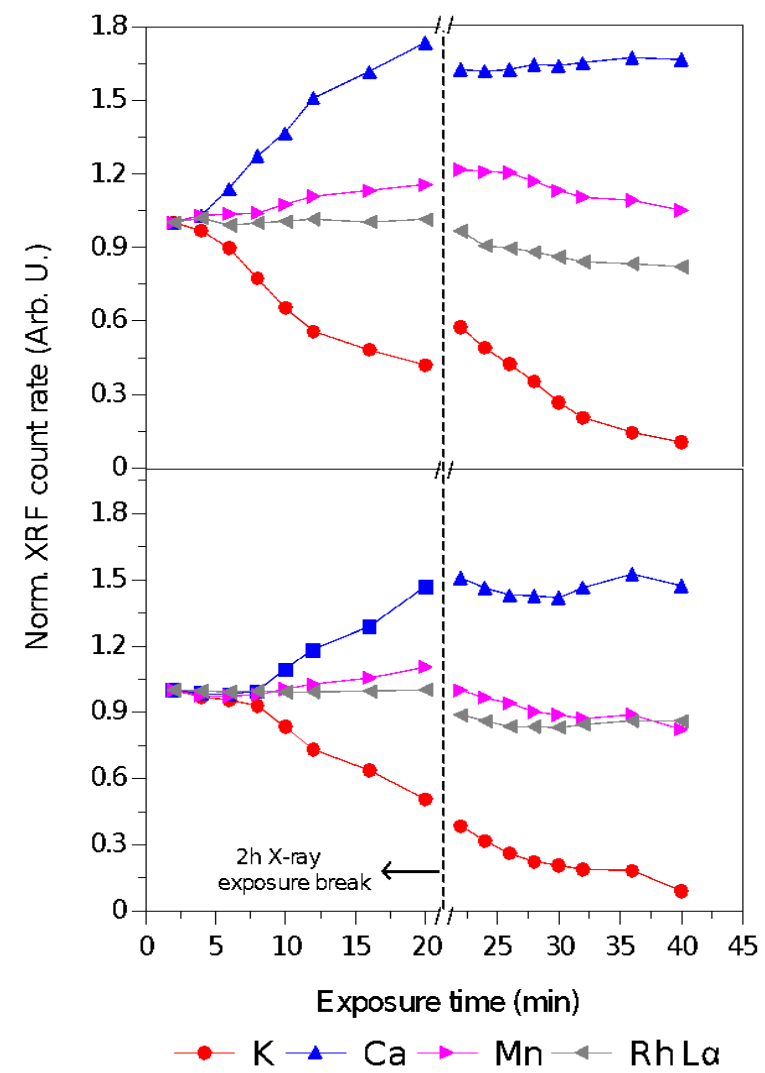

Figure S3. Normalized XRF K, Ca, Mn, and Rh L $\alpha$ count rate recorded on soybean leaves at V3 growth stage exposed to polycapillary focused $30 \mu \mathrm{m} X$-ray beam at $40.5 \mathrm{~W}(45 \mathrm{kV}$ and $900 \mu \mathrm{A})$ during two cycles of 20 minutes each, with a $2 \mathrm{~h}$ non-irradiation gap. The figures (A-B) encompass independent biological replicates.

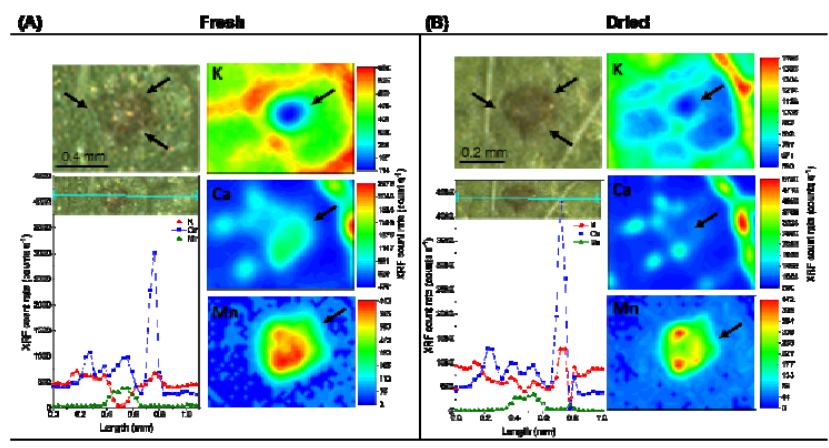

Figure S4. Photographs and XRF probing of $\mathrm{K}, \mathrm{Ca}$, and Mn spatial distribution on fresh (A) and dried (B) soybean leaves at V3 growth stage exposed to polycapillary focused $30 \mu \mathrm{m}$ X-ray beam at $40.5 \mathrm{~W}(45 \mathrm{kV}$ and 900 $\mu \mathrm{A})$ for 20 minutes. An 800-pixel XRF map and a 32point XRF linescan were carried out in each case. The analysis of the fresh leaf was carried out 24-h after the irradiations, whereas the dried ones after a 48 -h oven- drying at $60{ }^{\circ} \mathrm{C}$. Note that the irradiated leaf regions, pointer out with the black arrows, presents a necrotic spot and clear changes on the elemental distribution in both fresh and dried leaf tissues. Data resulting from an independent biological replicate.

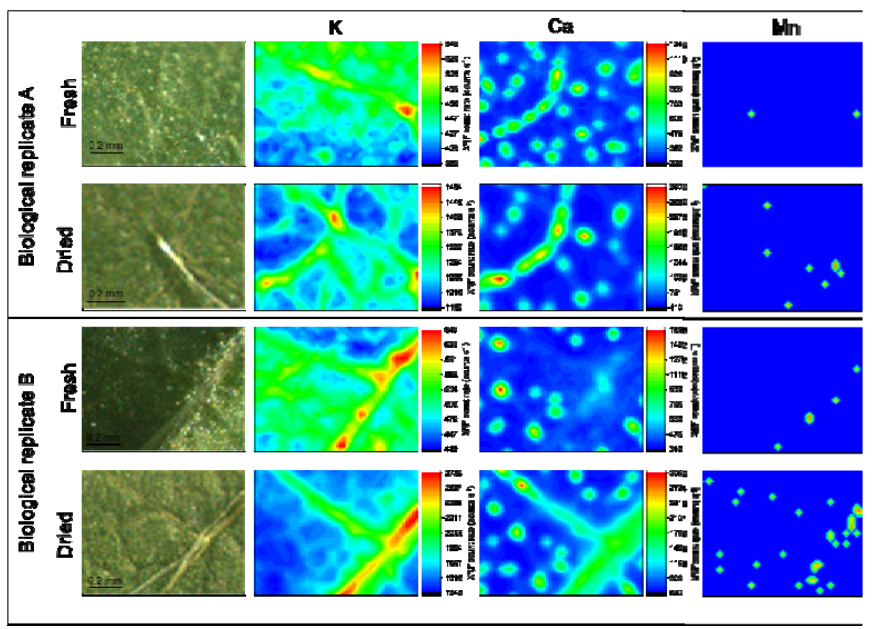

Figure S5. XRF probing maps of $\mathrm{K}, \mathrm{Ca}$, and $\mathrm{Mn}$ spatial distribution on fresh and dried soybean leaves at the V3 growth stage from two independent biological replicates exposed to a polycapillary focused $30 \mu \mathrm{m}$ X-ray beam at $40.5 \mathrm{~W}(45 \mathrm{kV}$ and $900 \mu \mathrm{A})$ for $10 \mathrm{~s}$. The analysis of the fresh leaf was carried out 24-h after the irradiations, whereas the dried ones after a 48 -h oven-drying at $60^{\circ} \mathrm{C}$.

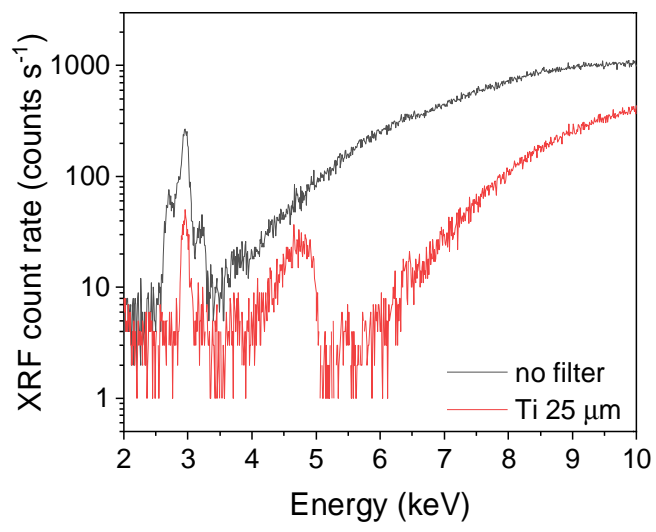

Figure S6. XRF spectra recorded with and without the 25 $\mu \mathrm{m}$-thick Ti primary filter selected on a plexiglass cube. The use of filter implies on a lower flux, thus a decrease in X-ray scattering is noticed. 
bioRxiv preprint doi: https://doi.org/10.1101/2022.01.18.476760; this version posted January 20, 2022. The copyright holder for this preprint (which was not certified by peer review) is the author/funder, who has granted bioRxiv a license to display the preprint in perpetuity. It is made available under aCC-BY-NC-ND 4.0 International license. 
bioRxiv preprint doi: https://doi.org/10.1101/2022.01.18.476760; this version posted January 20, 2022. The copyright holder for this preprint (which was not certified by peer review) is the author/funder, who has granted bioRxiv a license to display the preprint in perpetuity. It is made available under aCC-BY-NC-ND 4.0 International license. 
bioRxiv preprint doi: https://doi.org/10.1101/2022.01.18.476760; this version posted January 20, 2022. The copyright holder for this preprint (which was not certified by peer review) is the author/funder, who has granted bioRxiv a license to display the preprint in perpetuity. It is made available under aCC-BY-NC-ND 4.0 International license. 